\title{
Comparative Antimicrobial Activity of Areca catechu Nut Extracts using Different Extracting Solvents
}

\author{
MArifur Rahman ${ }^{1 *}$, Papeya Sultana ${ }^{2}$, M Sahidul Islam¹, M Toslim Mahmud ${ }^{1}$ M Mamun Or Rashid² and Foysal \\ Hossen $^{1}$ \\ ${ }^{1}$ Department of Microbiology, Noakhali Science \& Technology University, Sonapur, Noakhali 3814, Bangladesh, ${ }^{2}$ Department of Pharmacy, Noakhali \\ Science \& Technology University, Sonapur, Noakhali 3814, Bangladesh
}

\begin{abstract}
Scientists from different sectors are investigating plants for their antimicrobial usefulness. Studies have found thousands of plants which have inhibitory effects on a range of microorganisms in vitro. Surprisingly, only around $10 \%$ of all the plants have been investigated in this purpose. The antimicrobial properties of Areca catechu nut extract has been reported earlier. In our study, we have observed and compared the antibacterial activity among $\boldsymbol{n}$-hexane, ethanol and water extract of $A$. catechu nut. We found antimicrobial effect only from ethanol and water extract. On the contrary, there was no antibacterial effect observed from n-hexane extract. Furthermore, the extracts are effective only against gram positive bacteria. The ethanol extract concentration from $\mathbf{0 . 1 8 8 - 0 . 3 7 7} \mathrm{mg} / \mathrm{ml}$ was the minimum inhibitory concentration (MIC) for gram positive bacteria used in our study. While, minimum bactericidal concentrations (MBC) were 0.377-0.753 $\mathrm{mg} / \mathrm{ml}$ for this group of microorganisms. On the other hand, in case of water extract the MIC and MBC were 0.047-1.56 and 0.094-3.125 $\mathrm{mg} / \mathrm{ml}$ respectively for Gram-positive organisms. This study suggest that $A$. catechu nut extract can be a potential source for developing antibacterial agents against Gram-positive bacteria which are commonly found on human oral cavity and responsible for dental caries.
\end{abstract}

Keywords: Areca catechu, n-Hexane, Ethanol, Minimum inhibitory concentration (MIC), Minimum bactericidal concentrations (MBC)

\section{Introduction}

Areca nut tree (Areca catechu) is referred to as betel nut tree; which is a species of palm tree that grows in tropical humid regions like Asia Pacific and parts of east Africa ${ }^{1}$. In Bangladesh, it is well grown in coastal areas such as Bagerhat, Barisal, Jhalokati, Pirojpur, Noakhali, Barguna, Chittagong, Lakshmipur, and Cox's Bazar and so on. It is a medium-sized tree growing up to $20 \mathrm{~m}$ height, with a trunk $20-30 \mathrm{~cm}$ in diameter. The species is also vernacularly familiar as Puga in Sanskrit, Pinang in Malaysia and Supari in Bengali. The nuts, husks, young shoots, buds, leaves and roots of $A$. catechu are used in various medicinal preparations ${ }^{2}$. Globally around 600 million users most commonly within the Indian subcontinent and Southeast Asia spread its use through immigration and the availability of non-perishable refined products ${ }^{3}$. Areca nut is chewed wrapped in a betel leaf (Piper betel) along with calcium hydroxide (slaked lime) is a tradition, custom or ritual which dates back thousands of years in much of the geographical areas from South Asia eastward to the Pacific as stimulant and mouth freshener ${ }^{4}$. Worldwide areca nut chewing is the most commonly used addictive substance as like as the caffeine, nicotine and alcohol ${ }^{5}$. The nut is also used as a psychoactive drug ${ }^{6}$. The users often consider it harmless and report an increased capacity to work, a sense of well-being, euphoria, a warm sensation of the body, salivation, diaphoresis, a heightened alertness and combat against hunger and increased stamina due to arecoline alkaloid of areca nut extract ${ }^{7}$.

Besides, betel quid chewing has been reported to improve oral hygiene and motility of food and thereby reduce the absorption of dietary cholesterol ester as well as arrest the weight gain ${ }^{8-10}$. Pharmacological properties of betel nut components make it usable for many therapeutic purposes ${ }^{11}$. There are evidence on stroke recovery tool and treatment of schizophrenia (mental disorder $)^{11-13}$. A. catechu extract also has anti-aging effects due to the presence of CC-516 (A. catechu L. extract) which is used for improving skin hydration, skin elasticity and skin wrinkles suggesting a potential use for $\operatorname{cosmetics}^{14}$. The main chemical constituents of areca nut are polyphenols, fat, polysaccharides, fibre, and protein ${ }^{15}$. Besides these, areca nut contain catechin, tannins (15\%), Gallic acid fat, gum and alkaloids like arecoline $(0.1-0.7 \%)$ arecaine $(1 \%)$ and others in trace amounts such as arecadine, guvacoline, and guvacine ${ }^{16}$. These chemical components have been used as an anti-diabetic, blood pressure regulating activity, anti-ulceogenic, antioxidant activity, anticonvulsant activity, central nervous system (CNS) stimulant 
activity, oxytocic activity, anti-fertility, antihelmintic, antibacterial, antifungal effects and antiviral activity etc. ${ }^{17-18}$.

It has been reported that areca nut extract exerts a direct antimicrobial effect against Gram-positive oral bacteria and fungi, including Streptococcus mutans, Streptococcus salivarius, Candida albicans and Fusobacterium nucleatum ${ }^{19}$ Some of them are responsible for dental caries ${ }^{20}$. Tannic acid at a concentration varying from 1.8-18 mg/ml inhibits growth of $E$. corrodens, Prophyromonas gingivalis, C. rectus and Fusobacterium nucleatum ${ }^{19}$. Although little is known about the cariostatic properties of Areca it has been suggested that the betel stain, which often coats the surface of the teeth, may act as a protective varnish ${ }^{19}$. Study evaluated that it also has significant antiviral activity against the human immunodeficiency virus (HIV) 21. Although there are several reports on the adverse effects of areca nut, no systematic research has been conducted to determine its medicinal properties.

\section{Materials and Methods}

\section{Microorganisms}

Four ATCC bacterial cultures were used for antimicrobial test and to determine the MIC and MBC of Areca catechu nut extract. The ATCC cultures were collected from the Department of Microbiology, Dhaka Shishu (Children) Hospital and from the Department of Microbiology, University of Dhaka, Dhaka. The cultures were Staphylococcus aureus ATCC 25923, Bacillus subtilis ATCC 10707, Pseudomonas aeroginosa ATCC 27853, and Escherichia coli ATCC 25922.

\section{Extraction method for Areca catechu}

The extract of $A$. catechu was made by three different solvents; $n$-hexane, ethanol and water. At first, whole areca nut was purchased from the market and was transferred to the laboratory. The undesired residues were separated and the nuts were washed with sterile water to remove dust. The nuts were then dried at $40^{\circ} \mathrm{C}$ overnight in hot air oven. The dried nuts were grounded to powder in a grinder.

After that, $10 \mathrm{~g}$ of the powder were taken in a sterile Duran bottle and mixed with $40 \mathrm{ml}$ of $n$-hexane. The nut powder was stirred vigorously and was kept at $25^{\circ} \mathrm{C}$ overnight. Next, the suspension was filtered through a piece of sterile cotton fabric. The filtrate contained the n-Hexane extract which was dried at $40^{\circ} \mathrm{C}$ overnight to get solid extract and the residue was separated and discarded. The same procedures were followed to get extract of $A$. catechu nut by ethanol and water to get ethanol and water extracts. All dried extracts ( $n$-hexane, ethanol and water extract) were refrigerated at $4^{\circ} \mathrm{C}$ for further study.

\section{Assay of antibacterial activity of Areca catechu extracts}

The antibacterial activity was determined by disc diffusion method. We have followed the procedure of National Committee for Clinical Laboratory Standards (NCCLS) ${ }^{22}$. In a brief, MuellerHinton agar plates were prepared by dipping sterile swabs with reference bacterial cultures. The young cultures were suspended into normal saline and compared the turbidity with 0.5 McFarland standard. Next, previously prepared paper discs of each extract were placed on swab plates. The paper discs were prepared by impregnating the sterile paper discs $(3.5 \mathrm{~mm})$ into the solution of different nut extract ( $n$-hexane, ethanol and water extract). The solutions of all extracts were prepared at a concentration of 20 $\mathrm{mg} / \mathrm{ml}$ (by dissolving $20 \mathrm{mg}$ of each extract into $1 \mathrm{ml}$ of distilled water). There were also 'extract control' for each extract in which sterile paper discs were dipped into pure $n$-hexane, 95\% alcohol and water for $n$-hexane extract control, ethanol extract control and water extract control respectively. Finally, all soaked paper disc were air dried for 3 hours before placing on agar plates. Tetracycline antibiotic disc was used as a positive control for all organisms. The agar plates were incubated at $37^{\circ} \mathrm{C}$ for $24 \mathrm{~h}$ and the zone of inhibition were observed.

\section{Determination of the MIC and the MBC}

The MIC and the MBC were determined by Kirby-Bauer disc diffusion method ${ }^{23}$. Both disc diffusion and broth dilution methods were carried out. In the disc diffusion method, a 2 fold serial dilution was made for each extract to make suspension of different concentrations ranging 6.25-0.024 mg/ml. Individual paper discs were impregnated to each concentration and air dried for $3 \mathrm{~h}$ before placing on Mueller-Hilton agar plate that has already been swabbed with bacteria. The plates were incubated at $37^{\circ} \mathrm{C}$ for $24 \mathrm{~h}$. The MIC end point was determined as the lowest concentration of each extract, which inhibited the bacterial growth.

In the broth dilution method, an appropriate amount $(62.5 \mathrm{mg}$ extract plus $10 \mathrm{ml}$ respective solvent) of nut extract was dissolved in respective solvent to prepare a solution containing concentration $6.25 \mathrm{mg} / \mathrm{ml}$. Two fold dilutions of this solution in Mueller-Hilton broth were prepared and added to equal volume of bacterial suspension. The final concentration of each extracts was then one-half of the original concentration in each tube. After overnight incubation at $37^{\circ} \mathrm{C}$, the MIC end point was determined as the lowest concentration of the extract, at which there is no visible growth of bacteria. To determine the MBC, the liquid in each test tube was swabbed onto an agar plate. After overnight incubation at $37^{\circ} \mathrm{C}$, the last plated test tube with no bacterial growth on the agar plate was determined as the MBC.

\section{Results and Discussion}

Yield and physical properties of Areca catechu with different extract

The phytochemicals present in A. catechu were extracted to yield fractionated organic compounds from $10 \mathrm{~g}$ of nut. The extracts were then dried to obtain dried organic material and weighted. The yields were 1.032, 1.804 and $1.411 \mathrm{~g}$ for $n$-hexane, ethanol and water extract respectively (Figure 1). The colours of the dried n-hexane, ethanol and water extract were white, reddish and cherry red respectively.

Antimicrobial activity of n-hexane, ethanol and water extracts

The promising prospect of $A$. catechu is that it is a traditional habit of chewing with betel leaf rather than the use as antimicrobial agent. This study observed and compared the antimicrobial 


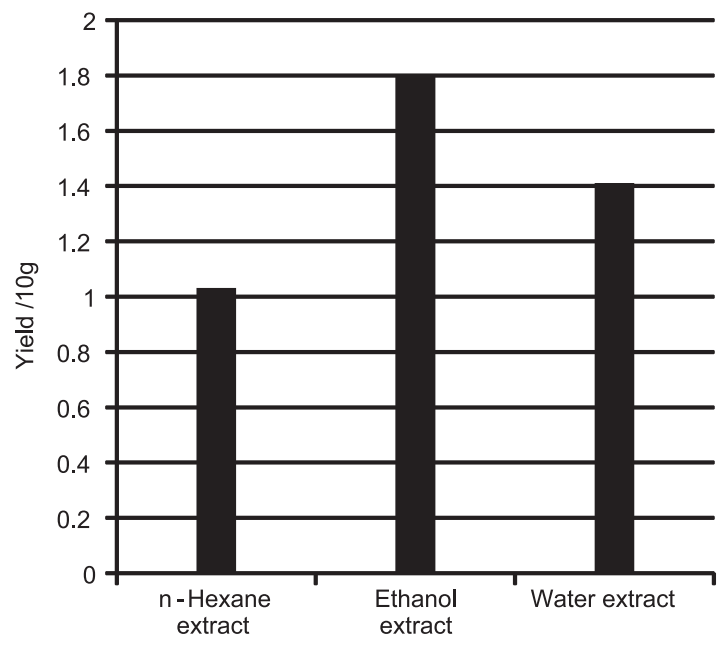

Figure 1. Yields of Areca catechu in different solvents.

activity of three different extract of $A$. catechu ( $n$-hexane extract, ethanol extract and water extract) against both gram positive and gram negative bacteria namely Staphylococcus aureus, Salmonella enterica serovars Typhi, Bacillus subtilis, Pseudomonas aeroginosa and Escherichia coli.

Fifty microlitre each of extracts at $20 \mathrm{mg} / \mathrm{ml}$ concentration was impregnated into paper disc and dried at $40^{\circ} \mathrm{C}$ for $3 \mathrm{~h}$. The discs were then applied on Mueller-Hilton agar plates in which the bacteria were impregnated beforehand. The agar plates were incubated overnight at $37^{\circ} \mathrm{C}$. Formations of clear zones were observed and summarized in Table 1.

The table shows the antibacterial activity of different solvent extracts of A. catechu. The ethanol and water extracts showed zone of inhibition against B. cereus and S. aureus (Figure 2A). Other extract showed no antibacterial activities against the bacterial species we used (Figure 2A). The zone of inhibition observed for both alcoholic and water extracts of areca nut against S. aureus and B. subtilis. The ranges of the zones were from 11$14 \mathrm{~mm}$. The reasons behind the difference in efficacy of different solvents extracts are yet to study, however; it might be due to varying degrees of solubility of the active constituents with the solvents ${ }^{24}$. The antagonized effects of the solvents with the constituents of Areca nut might responsible for no effect against bacteria ${ }^{25}$. This might be the reason for which $n$-hexane extract has no inhibitory effect on bacteria. There are number of evidence showed the efficacy of $A$. catechu nut extract against both gram positive and gram negative bacteria ${ }^{26}$. In our study, we did not found any activity of these three different Areca nut extract on gram negative bacteria (Escherichia coli ATCC 25922 and Pseudomonas aeroginosa ATCC 2785) (Figure 2B-C).

Table 1. Zone of inhibition of Areca catechu nut extracts

\begin{tabular}{lccccccc}
\hline & \multicolumn{6}{c}{ BacteriaZone of inhibition in millimetres (Concentration of each extract was 20 mg/ml) } \\
\cline { 2 - 8 } & $\begin{array}{l}n \text {-Hexane } \\
\text { extract: }\end{array}$ & $\begin{array}{c}n \text {-Hexane } \\
\text { control: }\end{array}$ & $\begin{array}{c}\text { Ethanol } \\
\text { extract: }\end{array}$ & $\begin{array}{c}\text { Ethanol } \\
\text { control: }\end{array}$ & $\begin{array}{c}\text { Water } \\
\text { extract: }\end{array}$ & $\begin{array}{c}\text { Water } \\
\text { control: }\end{array}$ & $\begin{array}{c}\text { Positive control } \\
\text { (Tetracycline) }\end{array}$ \\
& $\mathrm{n}(\mathrm{E})$ & $\mathrm{n}(\mathrm{C})$ & $\mathrm{E}(\mathrm{E})$ & $\mathrm{E}(\mathrm{C})$ & $\mathrm{W}(\mathrm{E})$ & $\mathrm{W}(\mathrm{C})$ & \\
\hline Escherichia coli & No & No & No & No & No & No & 14 \\
Pseudomonas aeroginosa & No & No & No & No & No & No & 11 \\
Bacillus subtilis & No & No & 13 & No & 12 & No & 17 \\
Staphylococcus aureus & No & No & 11 & No & 14 & No & 17 \\
\hline
\end{tabular}

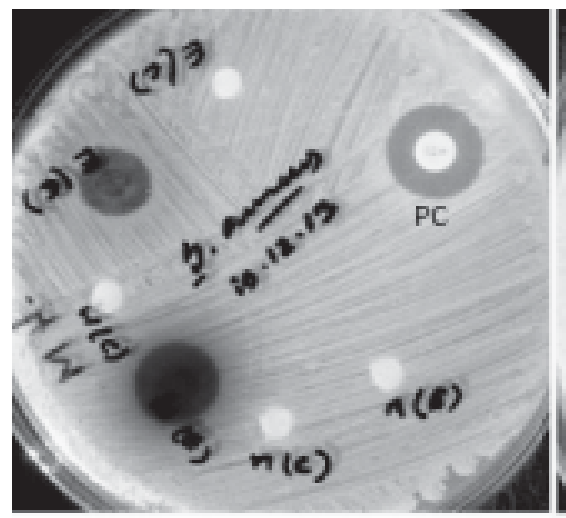

A

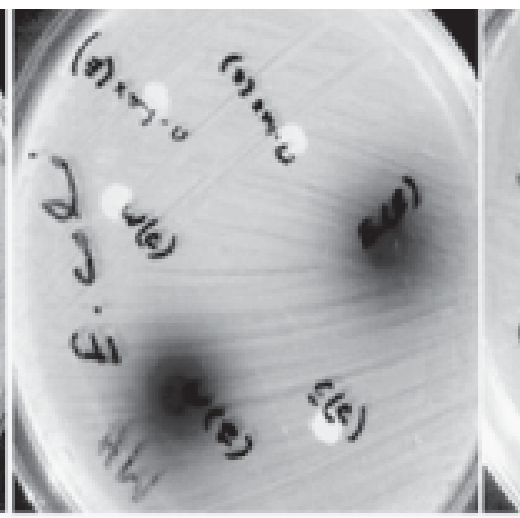

B

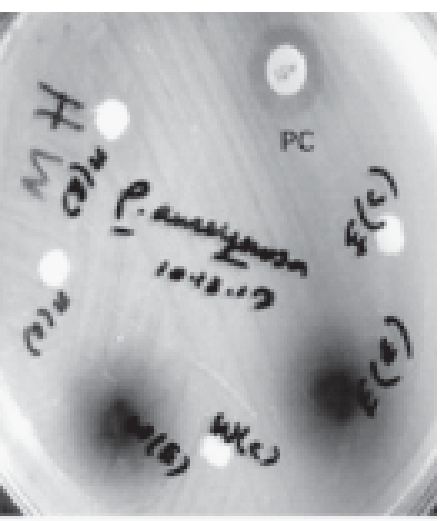

C

Figure 2: Zone of inhibition of different extracts of Areca catechu extracts $(20 \mathrm{mg} / \mathrm{ml})$ on the test bacteria. The cherry red color on agar plate is due to the colour of ethanol and water extract of nut. A = Staphy;ococcus aureus; (B) = Escherichia coli (No effect); $(C)=$ Pseudomonas auregenosa $($ No effect $) ; n(E)=n$-Hexane extract; $n(C)=n$-Hexane control; $E(E)=E$ thanol extract; $E(C)=$ Ethanol control; $W(E)=$ Water extract; $W(C)=$ Water control; $P C=$ Positive control (tetracycline disc). 
Determination of the MIC and the MBC of ethanol and water extracts of Areca catechu

The MIC and the MBC of $A$. catechu nut extracts have also been computed in this study. The MIC and the MBC for the organisms of interest were determined by agar diffusion test and tube dilution method. Agar diffusion test were carried out to determine the MIC of these extracts where the both extract (ethanol and water extracts) were diluted at concentrations ranging from 6.25-0.024 $\mathrm{mg} / \mathrm{ml}$ (Table 2 and Table 3). The individual paper discs were soaked into each dilution tube and the discs were then applied on Mueller-Hilton agar plates in which the tested bacteria were already been swabbed. The lowest concentration at which the inhibition of bacterial growth was observed was determined as the MIC (Figure 3). The MBC were determined by the tube dilution method with the procedure described in method section.

The MIC and the MBC values of ethanol extract were 0.377 and $0.753 \mathrm{mg} / \mathrm{ml}$ respectively for $B$. subtilis whereas; those values were 0.188 and $0.377 \mathrm{mg} / \mathrm{ml}$ accordingly for S. aureus (Table 2). On the other hand, the MIC and MBC values of water extract were $1.56 \mathrm{mg} / \mathrm{ml}$ and $3.125 \mathrm{mg} / \mathrm{ml}$ consecutively for B. subtilis while; in case of $S$. aureus those values were $0.094 \mathrm{mg} / \mathrm{ml}$ and $0.188 \mathrm{mg} / \mathrm{ml}$ accordingly for (Table 3 ). We have found that the MIC and the MBC values of ethanol extract were lower than the values of water extract for $B$. subtilis. On the other hand, in case of $S$. aureus the MIC and MBC values of ethanol extract were higher than the values of water extract (Figure 3).

A number other studies with different compounds (e.g., betel leaves, honey, propolis) have been carried out against varieties of bacteria including $B$. subtilis and $S$. aureus ${ }^{27-28}$. We also compared the efficacy of ethanol and water extract of $A$. catechu nut with other such compounds showing antibacterial activity. In our study, we found that the ethanol extract of A. catechu is more effective than the methanol or ethanol extract leaves of $P$. betel against above mentioned two bacteria ( MIC of betel leaves extract is $0.50 \mathrm{mg} / \mathrm{ml}$ for both bacteria which is higher than the MIC of ethanol extract of Areca nut ${ }^{27}$. In case of $S$. aureus, the MIC of water extract $(0.094 \mathrm{mg} / \mathrm{ml})$ was also to be shown lower than the leaves of $P$. betel extracts $(0.50 \mathrm{mg} / \mathrm{ml})^{27}$. Similarly, its

Table 2: The MIC and the MBC of the ethanol extract of Areca catechu

\begin{tabular}{lcccccccccc}
\hline Name of the organism & \multicolumn{7}{c}{ Concentration (mg/ml) } \\
& 6.25 & 3.125 & 1.56 & 0.753 & 0.377 & 0.188 & 0.094 & 0.047 & 0.024 \\
Bacillus subtilis & - & - & - & MBC & MIC & + & + & + \\
Staphylococcus aureus & - & - & - & - & MBC & MIC & + & + \\
\hline
\end{tabular}

$(-)$ = Represents inhibition; $(+)=$ Represents growth.

Table 3: The MIC and the MBC of the water extract of Areca catechu

\begin{tabular}{lccccccccc}
\hline Name of the organism & \multicolumn{9}{c}{ Concentration (mg/ml) } \\
& 6.25 & 3.125 & 1.56 & 0.753 & 0.377 & 0.188 & 0.094 & 0.047 \\
Bacillus subtilis & - & MBC & MIC & + & + & + & + & + \\
Staphylococcus aureus & - & - & - & - & - & MBC & MIC & + \\
\hline
\end{tabular}

$(-)=$ Represents inhibition; $(+)=$ Represents growth.

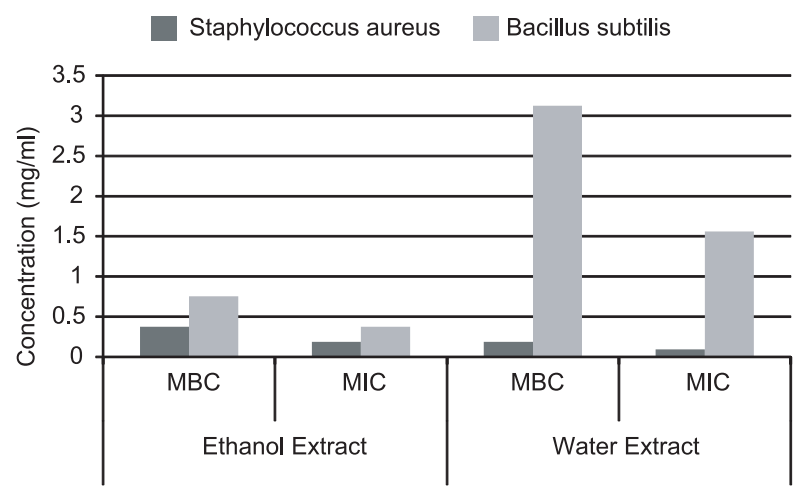

Figure 3: The MIC and the MBC concentrations $(\mathrm{mg} / \mathrm{ml})$ of ethanol and water extracts of Areca catechu. 
effectiveness was shown to be higher than the honey or propolis against S. aureus (MIC of propolis is 2.74- 3.5mg/ml and MIC of honey is $375 \mathrm{mg} / \mathrm{ml})^{28}$.

However, the efficacy is lower than the betel leaves extract in case of $B$. subtilis. This is because, the MIC of A. catechu nut extract is higher $(1.56 \mathrm{mg} / \mathrm{ml})$ than the MIC of $P$. betel leaves extract $(0.50 \mathrm{mg} / \mathrm{ml})^{27}$ Due to the unavailability of data it was not possible to compare between the MIC of honey or propolis and MIC of A. catechu nut extract for B. subtilis.

\section{Conclusion}

Areca catechu nut extract showed antibacterial agents against Gram-positive bacteria. To determine the highest efficacy and optimum concentration of A. catechu nut extract as antibacterial drug, more investigation is needed using purified components with different other solvents in various doses.

\section{Acknowledgement}

The authors are grateful to the Department of Microbiology and the Department of Pharmacy, Noakhali Science and Technology University for technical supports and valuable suggestions during this research work.

\section{References}

1. Anonymous. 2015. Areca nut. Available at: http://en.wikipedia.org/ wiki/Areca_nut. Accessed 12 March 2015.

2. Staples GW and Bevacqua RF. 2006. Areca catechu (betel nut palm), ver. 1.3. In Species Profiles for Pacific Island Agroforestry (Elevitch $\mathrm{CR}$ ed), Vol 8, pp 1-17. Permanent Agriculture Resources (PAR), Ho lualoa, HI.

3. Winsock AR. 2013. Principles of Addiction Comprehensive Addictive Behaviors and Disorders, Chapter 87: Areca Nut, Betel Quids, and Associated Products, pp 863-872. Academic Press, London.

4. Gupta PC and Ray CS. 2004. Epidemiology of betel quid usage. Ann Acad Med Singapore. 33(4): 31-36.

5. Auluck A, Hislop G, Poh C, Zhang L and Rosin MP. 2009. Areca nut and betel quid chewing among South Asian immigrants to Western countries and its implications for oral cancer screening. Rural Remote Health. 9(2): 11-18.

6. Boucher BJ and Mannan N. 2002. Metabolic effects of the consumption of Areca catechu. Addiction Biol. 7(1): 103-110.

7. Chu NS. 2002. Neurological aspects of areca and betel chewing. Addiction Biol. 7(1): 111-114.

8. $\quad$ Ling LJ, Hung SL, Tseng SC, Chen YT, Chi LY, Wu KM and Lai YL. 2001. Association between betel quid chewing, periodontal status and periodontal pathogens. Oral Microbiol Immunol. 16(6): 364-369.

9. Park YB, Jeon SM, Byun SJ, Kim HS and Choi MS. 2002. Absorption of intestinal free cholesterol is lowered by supplementation of Areca catechu L. extracts in rats. Life Sci. 70(16): 1849-1859.

10. Mannan N, Boucher BJ and Evans SJ. 2000. Increased waist size and weight in relation to consumption of Areca catechu (betel-nut): A risk factor for increased glycaemia in Asians in east London. $\mathrm{Br} \mathrm{J}$ Nutr. 83(3): 267-275.

11. Sullivan RJ, Allen JS, Otto C, Tiobech J and Nero K. 2000. Effects of chewing betel nut (Areca catechu) on the symptoms of people with schizophrenia in Palau, Micronesia. Br J Psychiatr. 177: 174-178.
12. Trivedy CR, Craig G and Warnakulasuriya S. 2002. The oral health consequences of chewing areca nut. Addiction Biol. 7(1): 115-125.

13. Hung SL, Lin YW, Wang YH, Chen YT, Su CY and Ling LJ. 2002. Permeability of Streptococcus mutans and Actinobacillus actinomycetemcomitans through guided tissue regeneration membranes and their effects on attachment of periodontal ligament cells. J Periodontol. 73(8): 843-851.

14. Lee KK and Choi JD. 1999. The effects of Areca catechu L extract on anti-aging. Int J Cosmet Sci. 21(4): 285-295.

15. Reena R, Authikat N and Michael A. 2009. Study on the Areca nut for its antimicrobial properties. Pharmacognosy. 1(1): 42-45.

16. Joshi M, Gaonkar K, Mangoankar S and Satarkar S. 2012. Pharmacological investigation of Areca catechu extracts for evaluation of learning, memory and behavior in rats. Int Curr Pharma J. 1(6): 128-132.

17. Peng W, Liu YJ, Wu N, Sun T, He XY, Gao YX and Wu CJ. 2015. Areca catechu L. (Arecaceae): A review of its traditional uses, botany, phytochemistry, pharmacology and toxicology. $J$ Ethnopharmacol. 164: 340-356.

18. Patil PR, Rakesh SU, Dhabale PN and Burade KB. 2009. Pharmacological activities of Areca catechu Linn. A review. $J$ Pharmacy Res. 2(4): 683-687.

19. de Miranda CM, van Wyk CW, van der Biji P and Basson NJ. 1996. The effect of areca nut on salivary and selected oral microorganisms. Int Dental J. 46(4): 350-356.

20. Jørn AA, Ann LG, Sara RD, Alice ML, Ingar O, Floyd ED, Eugene JL and Bruce JP. 2008. Bacteria of dental caries in primary and permanent teeth in children and young adults. J Clin Microbiol. 46(4): 1407-1417.

21. Kusumoto IT, Nakabayashi T, Kida H, Miyashiro H, Hattori M, Namba T and Shimotohno K. 1995. Screening of various plant extracts used in ayurvedic medicine for inhibitory effects on human immunodeficiency virus type 1 (HIV-1) protease. Phytotherapy Res. 9(3): 180-184.

22. NCCLS. 1996. Protocols for evaluating dehydrated Mueller-Hinton agar. Approved Standard M6-A. National Committee for Clinical Laboratory Standards (NCCLS), Wayne, Pennsylvania.

23. Bauer AW, Kirby WMM, Sherris JC and Turck M. 1966. Antibiotic susceptibility testing by a standardized single disc method. Am J Clin Pathol. 45(4): 493-496.

24. Al-Reza S, Vivek B and Kang SC. 2009. Antioxidant and antilisterial effect of seed essential oil and organic extracts from Zizyphus jujube. Food Chem Toxicol. 47(9): 2374-2380.

25. Parekh J and Chanda S. 2007. Antimicrobial and phytochemical studies on twelve species of Indian medicinal plants. African J Biomed Res. 10: 175-181.

26. Chin A, Fernandez CD, Sanchez RB, Santos BMS, Tolentino RF and Masangkay FR. 2013. Antimicrobial preference of ethanolic extract of Areca catechu L seeds against mixed-oral flora from tooth scum and gram negative laboratory isolates. Int $J$ Res Ayurveda Pharm. 4(6): 876-880.

27. Swapna NL, Ammani K and Prasad SHKR. 2013. In vitro studies on bacteriostatic effects of solvent extracts of Kodithotakalli leaves of Piper betel L. Cv. Kapoori A local cultivar: RJPBCS. 4(1): 378-385.

28. Rahman MM, Richardson A and Sofian-Azirun M. 2010. Antibacterial activity of propolis and honey against Staphylococcus aureus and Escherichia coli. African J Microbio. Res. 4(16): 1872-1878. 